\title{
Sobre la condena por prevaricación del Magistrado Baltasar Garzón por la intervención de las comunicaciones autorizada con ocasión de la instrucción del caso Gürtel: La sentencia de la Sala de lo Penal del Tribunal Supremo de 9 de febrero de 2012
}

\author{
María Luz Martínez Alarcón \\ Profesora Titular de Derecho Constitucional \\ Universidad de Castilla-La Mancha
}

Recibido: 29.03.2012

Aceptado: 31.05 .2012

Resumen: Recientemente, el Tribunal Supremo español ha condenado a D. Baltasar Garzón por un delito de prevaricación dolosa como consecuencia de su decisión de autorizar la intervención de las comunicaciones habidas entre los internos en establecimiento penitenciario con sus representantes legales en la trama Gürtel. La resolución ha suscitado opiniones encontradas en los ámbitos políticos e intelectuales del país. Este artículo pretende destacar que, a pesar de la dificultad existente para concluir que, en este supuesto, se ha producido una inobservancia manifiesta del Derecho aplicable, tampoco sorprende la conclusión jurídica a la que finalmente ha llegado el tribunal.

Palabras clave: Interceptación, comunicaciones, abogados, prisioneros, Gürtel.

Abstract: Recently, the Spanish Supreme Court has condemned Baltasar Garzón as a result of his decision of intervention of communications between some prisoners and their lawyers in the Gürtel case. The sentence has provoked opposite intellectual and political opinions in the country. This article tries to emphasize that it is difficult to demonstrate a manifest nonobservance of the applicable law in this case. But also that the legal conclusion at which the court has finally arrived is not surprising.

Key words: Interception, communications, lawyers, prisoners, Gürtel.

Sumario: I. Sobre las condiciones de constitucionalidad de la limitación del derecho al secreto de las comunicaciones. Con especial referencia a la limitación de las comunicaciones de los internos en establecimiento penitenciario con sus representantes legales.-II. Comentario a la Sentencia de la Sala de lo Penal del Tribunal Supremo de 9 de febrero de 2012: 1. La afectación del derecho de defensa. 2. La condena por prevaricación de D. Baltasar Garzón en el caso Gürtel: 2.1. Consideraciones preliminares sobre la existencia de responsabilidad penal del juzgador por el ejercicio de la función jurisdiccional. 2.2. El elemento objetivo del ilícito: La ausencia de una conducta racional y secundum legem. 2.3. El elemento subjetivo del ilícito (el dolo).-III. Referencia bibliográfica. 


\section{SOBRE LAS CONDICIONES DE CONSTITUCIONALIDAD DE LA LIMITACIÓN DEL DERECHO AL SECRETO DE LAS COMUNICA- CIONES. CON ESPECIAL REFERENCIA A LA LIMITACIÓN DE LAS COMUNICACIONES DE LOS INTERNOS EN ESTABLECI- MIENTO PENITENCIARIO CON SUS REPRESENTANTES LEGA- LES}

Los derechos fundamentales no son -salvo quizás el derecho fundamental a no ser torturado del artículo 15 del texto constitucional ${ }^{1}-$ derechos absolutos. Todos ellos se encuentran sometidos a límites, aunque es cierto que su limitación debe ser una práctica excepcional (regla igualmente aplicable al derecho al secreto de las comunicaciones). Por lo que hace precisamente a este derecho, su intervención debe producirse respetando las siguientes condiciones de constitucionalidad: Habilitación legal previa ${ }^{2}$, intervención judicial, pretensión de conseguir algún fin constitucionalmente lícito y proporcionalidad de la medida.

Dejando ahora a un lado las cuestiones relativas a la consecución del fin constitucionalmente lícito y al juicio de proporcionalidad y centrándonos en las dos primeras condiciones, hay que destacar la insuficiencia de la calidad normativa $^{3}$ de los preceptos que, en nuestro ordenamiento jurídico, regulan

${ }^{1}$ El artículo $15 \mathrm{CE}$ establece que "Todos tienen derecho a la vida y a la integridad física y moral, sin que, en ningún caso, puedan ser sometidos a tortura ni a penas o tratos inhumanos o degradantes...". Ahora bien, como se ha dicho, la relativización vuelve a surgir a la hora de interpretar el concepto de tratos inhumanos y degradantes; MARTÍN MORALES, R., El régimen constitucional del secreto de las comunicaciones, ed. Cívitas, Madrid, 1995, p. 36.

${ }^{2}$ El Tribunal Constitucional, así como un sector mayoritario de la doctrina en España, han entendido que, a pesar de la formulación del derecho al secreto de las comunicaciones contenida en el artículo 18.3 CE, resulta absolutamente necesaria una habilitación legal previa que predetermine las condiciones a las que ha de quedar sujeta cualquier limitación del mismo. En cualquier caso, la redacción de este precepto ha dado lugar a dos interpretaciones encontradas en el seno de la doctrina constitucional española. Para algunos autores, resulta constitucionalmente posible limitar el derecho al secreto de las comunicaciones a través de la resolución judicial sin que medie habilitación legal previa (aunque ésta, naturalmente, resulte conveniente). Para otros, la mayoría, la resolución judicial opera como una premisa básica, aunque no suficiente, de la limitación del derecho fundamental. Y es que entienden que la restricción del derecho exige necesariamente la existencia de un previo desarrollo legislativo habilitante que predetermine las condiciones de la limitación del derecho. Un ejemplo de los primeros podría ser RODRÍGUEZ RUIZ, B., El secreto de las comunicaciones: tecnología e intimidad, MacGraw-Hill, Madrid 1998, pp. 104-107. Entre los segundos, podríamos citar a LÓPEZ YAGÜES, V., La inviolabilidad de las comunicaciones con el Abogado defensor, ed. Tirant lo Blanch, Valencia 2003, p. 105; MARTÍN MORALES, R., El régimen constitucional del secreto de..., ob. cit., p. 39; o a JIMÉNEZ CAMPO, J., "La garantía constitucional del secreto de las comunicaciones", Revista Española de Derecho Constitucional, núm. 20, 1987, p. 58 y ss.

${ }^{3}$ La STEDH de 24 de agosto de 1998 (asunto $L A M B E R T$ ) señala que el requisito que recoge el artículo $8 \mathrm{CEDH}$ ("previsto por la ley") no es suficiente porque, además, la ley 
la intervención de las comunicaciones en el proceso penal (especialmente cuando se trata de las telefónicas). En efecto, ni la regulación contenida en el artículo 579 de la Ley de Enjuiciamiento $\mathrm{Criminal}^{4}$, ni la especial atinente a los internos en establecimiento penitenciario, recogida en la Ley Orgánica General Penitenciaria y desarrollada en su reglamento, recogen las previsiones necesarias para evitar que se produzcan intervenciones arbitrarias en las comunicaciones. Recordemos que el Estado español ha sido condenado por el Tribunal Europeo de Derechos Humanos en dos ocasiones con motivo de la insuficiencia de la regulación española sobre este asunto. La primera por sentencia de 30 de julio de 1998 (caso Valenzuela Contreras). Y la segunda por sentencia de 18 de febrero de 2003 (caso Prado Bugallo). En el primer caso, y aún a pesar de reconocer la labor de los tribunales españoles orientada a fortalecer las garantías de esta intervención (aunque señalando que dicha jurisprudencia era en todo caso posterior a los hechos enjuiciados), el Tribunal echa en falta en el código procesal criminal, en particular, la definición de las categorías de personas susceptibles de ser sometidas a vigilancia, la naturaleza de las infracciones que permiten la intervención de las comunicaciones, la fijación de un límite temporal de ejecución de la medida y el procedimiento para la utilización y destrucción de las grabaciones realizadas así como para la elaboración de los informes resumidos de las conversaciones interceptadas ${ }^{5}$. En el segundo, el Tribunal, aún reconociendo cierto carácter meritorio a la regulación de la intervención de las comunicaciones telefónicas introducida por el artículo 579 de la Ley de Enjuiciamiento Criminal, considera que dicho

ha de tener "calidad". Sobre los requisitos de calidad de la ley a los que se refiere el Tribunal de Estrasburgo véase CATALÀ I BAS, A.H., "Escuchas telefónicas: un encuentro con el Tribunal Constitucional y un desencuentro con el legislador español", Revista Europea de Derechos Fundamentales, núm. 15, 2010, p. 280 y ss.

${ }^{4}$ Las expectativas que generó la LO 4/1988, de 25 de marzo, de reforma de la LECrim, que introdujo el artículo 579 LECrim regulando por vez primera el régimen general de intervención de las comunicaciones telefónicas en España, corren paralelas a la decepción que han experimentado aquellos que se han aproximado al contenido del precepto. Entre otros, ELVIRA PERALES, A. "El derecho al secreto de las comunicaciones telefónicas a golpe de jurisprudencia”, ESTUDIOS SOBRE LA CONSTITUCIÓN ESPAÑOLA: Homenaje al profesor Jordi Solé Tura, Cortes Generales, CEPC, Universitat de Barcelona y Ajuntament de Mollet del Vallés, Madrid 2008, p. 1144.; LÓPEZ YAGÜES, V., La inviolabilidad de las comunicaciones con el abogado..., ob. cit., pp. 77-80; REBOLLO DELGADO, L., "El secreto de las comunicaciones: problemas actuales", Revista de Derecho Político, núms. 48-49, p. 380; LÓPEZ-FRAGOSO ÁLVAREZ, T., Las intervenciones telefónicas en el proceso penal, ed. Colex, Madrid 1991, pp. 41-42; LÓPEZ BARJA DE QUIROGA, J., Las escuchas telefónicas y la prueba ilegalmente obtenida, ed. Akal, Madrid, 1989, p. 182.

${ }^{5}$ Existen pronunciamientos anteriores de este Tribunal (aunque no relativos al Estado español) en los que ya se indican las previsiones que debe contener una regulación de intervención de las comunicaciones de calidad (sentencia del Tribunal Europeo de Derechos Humanos de 24 de abril de 1990 -asunto Kruslin-. 
precepto no colma las garantías exigidas para la intervención del derecho, y, en particular, indica que la norma española no establece -y debería hacerlola naturaleza de las infracciones que pueden dar lugar a escuchas, la fijación de límites sobre el plazo de duración de la medida, u otras cuestiones relativas a garantías procesales tales como la verificación judicial o el control de las cintas.

Nuestro Tribunal Constitucional ha reconocido este déficit normativo que, por cierto, no ha sido solventado por el legislador ${ }^{6}$. Aunque también ha afirmado que este vicio no puede provocar la estimación de un recurso de amparo. Antes bien, el pronunciamiento de amparo en este punto dependerá de la configuración final de la intervención judicial ${ }^{7}$, que deberá ceñirse a lo dispuesto por la prolija doctrina jurisprudencial que se ha desarrollado sobre la materia a tres niveles -internacional, constitucional y ordinario- y sin la cual no resulta posible aprehender el alcance y los límites del derecho al secreto de las comunicaciones en nuestro país en la actualidad ${ }^{8}$.

Conforme a esta doctrina jurisprudencial, que integra la motivación en el contenido esencial del derecho9, la autorización judicial de intervención de las comunicaciones -la limitación del derecho sólo la puede autorizar el órgano judicial actuando secundum legem ${ }^{10}$ - debe determinar con la mayor pre-

${ }^{6}$ El TEDH, en su sentencia Abdulkadir Coban c. España, de 26 de septiembre de 2006, constata que la jurisprudencia española ha incorporado su doctrina en materia de garantías, y, por lo tanto, aunque considera deseable la modificación del artículo 579 LECrim, señala que la incorporación de dicho cuerpo doctrinal jurisprudencial colma las exigencias del CEDH. Al respecto CANO PALOMARES, G., "El diálogo entre tribunales y el derecho al secreto de las comunicaciones telefónicas (a propósito de la decisión Coban c. España del Tribunal Europeo de Derechos Humanos de 25 de septiembre de 2006)", Revista Española de Derecho Europeo, núm. 24, 2007.

${ }^{7}$ Sobre este punto, las SSTC 26/2006, de 30 de enero FJ 50; 220/2006, de 3 de julio, FJ $2^{\circ} ; 219 / 2006$, de 3 de julio, FJ $2^{\circ}$; 184/2003, de 23 de octubre, FJ 6º; 49/1999, de 5 de abril, FJ $5^{\circ}$.

${ }^{8}$ En este sentido ELVIRA PERALES, A., "El derecho al secreto de las comunicaciones telefónicas a golpe de...”, ob. cit., p. 1146; LÓPEZ YAGÜES, V., La inviolabilidad de las comunicaciones con el Abogado..., ob. cit., p. 129. En España, el Auto del Tribunal Supremo de 18 de junio de 1992, (caso Naseiro) resulta fundamental en la concreción de los extremos que debe recoger una autorización judicial de intervención de las comunicaciones. Esta jurisprudencia ha sido posteriormente recogida y en ocasiones perfilada por otras resoluciones del propio Tribunal Supremo y del Tribunal Constitucional.

${ }^{9}$ Entre otras, SSTC 49/1999, de 5 de abril, FJ 7º; 299/2000, de 11 de diciembre, FJ 4 ${ }^{\text {; }}$; 167/2002, de 18 de septiembre, FJ $2^{\circ}$ ). La motivación es exigible también cuando se decide la prórroga de la intervención o nuevas intervenciones acordadas sobre la base de datos obtenidos durante una intervención autorizada previamente (por todas, STC 26/2010, de 27 de abril, FJ $2^{\circ}$ ).

${ }^{10}$ Únicamente en los casos de suspensión se podría prescindir de lo que es una autorización judicial propiamente dicha, aunque no de la necesaria intervención judicial (aunque sea a posteriori). Por ello resulta inconstitucional la regulación contenida en el artículo 51.5 de la Ley Orgánica Penitenciaria que faculta al Director del establecimiento 
cisión posible cuáles son las razones jurídicas y fácticas que justifican la intervención, es decir, cuál es el presupuesto legal habilitante de la intervención y cuáles los presupuestos materiales que la estimulan. En este último sentido, la resolución judicial debe concretar los datos objetivos indiciarios de la posible comisión de un hecho delictivo. Es decir, la intervención de las comunicaciones durante un sumario únicamente se puede producir cuando existan indicios o datos suficientes dotados de una objetividad bastante como para que resulten comunicables a terceros y susceptibles de comprobación en un proceso penal ${ }^{11}$. Porque dicha intervención no se puede producir con un fin meramente prospectivo, es decir, "para ver qué pasa y no porque en realidad se pueda decir que ha pasado o esté a punto de pasar algo relevante"12.

La intervención, además, así lo han dicho tanto el Tribunal Constitucional como el Supremo, solamente es posible en los supuestos de presunta comisión de un hecho delictivo grave (nunca por ilícitos administrativos e ilícitos penales leves). La gravedad de la infracción punible no viene determinada solo por la calificación de la pena legalmente prevista (aunque sea un factor a considerar), sino que también han tenerse en cuenta otros factores tales como la relevancia social de la infracción y de los bienes jurídicos que protege, debiendo analizarse las circunstancias concurrentes en el momento de su aplicación ${ }^{13}$. Por otra parte, la autorización judicial tiene que explicitar la conexión

penitenciario para decidir sobre la suspensión o intervención de las comunicaciones orales y escritas del preso dando cuenta a la autoridad judicial competente; REVIRIEGO PICÓN, F., "El secreto de las comunicaciones en los centros penitenciarios: Comunicaciones escritas "entre" reclusos", UNED. Boletín de la Facultad de Derecho, núm. 26, 2005, p. 576; MARTÍNEZ ESCAMILLA, M., La suspensión e intervención de las comunicaciones del preso, ed. Tecnos, Madrid 2000, pp. 576-577.

${ }^{11}$ Sobre esta cuestión se puede encontrar una gran cantidad de jurisprudencia. Haciendo un repaso de la última del Tribunal Constitucional al respecto podemos mencionar, entre otras, las sentencias 5/2010, de 7 de abril, FJ 2º 26/2010, de 27 de abril, FJ $2^{\circ}$; 148/2009, de 15 de junio, FJ $2^{\text {o }}$; 197/2009, de 28 de septiembre, FJ 4º $220 / 2009$, de 21 de diciembre, FJ 4º; 219/2009, de 21 de diciembre, FJ 4; 26/2006, de 30 de enero, FJ 6º 136/2006, de 8 de mayo, FJ 4; 146/2006, de 8 de mayo, FJ 2º; 220/2006, de 3 de julio, FJ $3^{\text {o }}$; 253/2006, de 11 de septiembre, FJ $2^{\circ} ; 150 / 2006$, de 22 de mayo, FJ $3^{\circ} ; 165 / 2005$, de 20 de junio, FJ $4^{\text {o }} ; 259 / 2005$, de 24 de octubre, FJ $2^{\circ} ; 261 / 2005$, de 24 de octubre, FJ $2^{\circ} ; 184 / 2003$, de 23 de octubre, FJ 11 ${ }^{\circ}$; 82/2002, de 22 de abril, FJ 3 ${ }^{\circ}$; 167/2002, de 18 de septiembre, FJ $2^{\circ}$; 14/2001, de 29 de enero, FJ 5 $;$; 138/2001, de 18 de junio, FJ $3^{\circ} ; 202 / 2001$, de 15 de octubre, FJ 4º 199/2000, de 11 de diciembre, FJ 4º; 49/1999, de 5 de abril, FJ 8º; 166/1999, de 27 de septiembre, FJ $8^{\circ} ; 171 / 1999$, de 27 de septiembre, FJ $8^{\circ}$. En el ámbito internacional véase, por ejemplo, las SSTEDH de 5 de junio de 1997 (caso $L \ddot{U} D I$ ) y de 6 de septiembre de 1978 (caso KLASS).

12 ANDRÉS IBÁNEZZ, P., "Las garantías del imputado en el proceso penal”, Revista Mexicana de Justicia, núm. 6, 2005, p. 20.

${ }^{13}$ Esta doctrina ha justificado la intervención de las comunicaciones respecto de delitos vinculados con la salud pública (tráfico de drogas), delitos de contrabando de tabaco y aquellos que utilizan tecnología electrónica. Véase, al respecto, las SSTC 136/2006, de 8 de mayo, FJ $5^{\circ}$ a) y b); 104/2006, de 3 de abril, FJ 3; 167/2002, de 18 de septiembre, FJ 
con el delito de las personas afectadas por la intervención ${ }^{14}$, el número o números de teléfono que deben ser intervenidos, la duración de la medida (el plazo máximo de intervención de las comunicaciones ${ }^{15}$ ), quiénes han de ejecutarla y cómo, y los periodos de rendición de cuentas ante el juez para permitir la fiscalización jurisdiccional de su ejecución así como de los soportes que contengan las grabaciones. En todo caso, y aunque es deseable que la resolución judicial que autoriza la intervención contenga todos estos datos, la jurisprudencia constitucional admite la motivación por remisión, y, así, la resolución judicial puede considerarse suficientemente motivada si, integrada con la solicitud policial, a la que puede remitirse, contiene todos los elementos necesarios para llevar a cabo el juicio de proporcionalidad.

Ahora bien, la intervención de las comunicaciones en un supuesto como el que nos va a ocupar, relativo a la escucha de las que se producen entre los representantes legales y sus clientes, plantea sus propias especificidades habida cuenta los derechos y bienes constitucionales que se encuentran en juego (el derecho fundamental a la asistencia letrada y defensa técnica, y a su través,

$4^{\text {o; }}$ 299/2000, de 11 de diciembre, FJ 20; 166/1999, de 27 de septiembre, FJ $3^{\circ}$ a), entre otras.

${ }^{14}$ Aunque el Tribunal Constitucional, en determinadas sentencias, ha destacado la importancia de identificar a las concretas personas investigadas como usuarias del teléfono objeto de la intervención, lo cierto es que también ha afirmado que la previa identificación de los titulares o usuarios de las líneas a intervenir no resulta siempre imprescindible (así, no se puede negar legitimidad constitucional a aquellas intervenciones telefónicas que, recayendo sobre sospechosos, se oriente a su identificación; ni se puede otorgar relevancia constitucional a cualquier error respecto a la identidad de los titulares o usuarios de las líneas a intervenir). Y es que a la vista de los avances en el ámbito de la telefonía -por ejemplo, la aparición de teléfonos móviles y tarjetas prepago que dificultan la identificación de los titulares y usuarios al facilitar el intercambio de los teléfonos- esas exigencias resultarían desproporcionadas; SSTC 150/2006, de 22 de mayo, FJ 3º; 104/2006, de 3 de abril, FJ $5^{\circ}$.

${ }^{15}$ El Tribunal Constitucional, rectificando la jurisprudencia del Tribunal Supremo, ha establecido que el plazo debe computarse, por razones de seguridad y para evitar afectar a las necesarias garantías del derecho, desde la fecha de la resolución judicial que autoriza la intervención (y no desde el momento en que la intervención se haga efectiva); inicialmente en la STC 205/2005, de 18 de julio, FJ $5^{\circ}$; ratificándose posteriormente, entre otras, en las SSTC 26/2006, de 30 de enero, FJ 9 ${ }^{\circ}$ 26/2010, de 27 de abril, FJ $4^{\circ}$. Sin embargo, algunas de estas decisiones del Tribunal Constitucional han venido acompañadas por el voto particular del Magistrado D. Ramón Rodríguez Arribas, quien sostenía que el dies a quo debería empezar a computar, normalmente, desde la fecha del Auto que autoriza la intervención, pero también, si fuera distinto, desde el día en que se comunique la autorización a los agentes de policía que hayan de efectuar la diligencia e incluso el día de la efectiva intervención del teléfono (siempre que el tiempo transcurrido desde la comunicación del Auto a la policía y la práctica de la intervención fuera razonablemente breve y justificadas las causas técnicas por las que no pudo llevarse a efecto con más diligencia, y así lo admitiera el órgano jurisdiccional al ejercer el control de dicha restricción del secreto de las comunicaciones). 
el más amplio derecho de defensa que garantiza el artículo 24.2 de la Constitución). En efecto, es evidente que el derecho a comunicar de forma reservada con el Abogado defensor es presupuesto del derecho de defensa. "El letrado no podrá aconsejar correctamente y defender con eficacia a su cliente más que en el caso de que posea un perfecto conocimiento de los hechos; sin embargo, es probable, si no seguro, que ese flujo de información imprescindible para el éxito de la estrategia defensiva no llegue a tener lugar si el imputado alberga la más mínima sospecha de que ciertos datos -y, en particular, aquellos que le incriminan- pueden salir de la esfera de esa relación"16. Por ello, resulta también evidente que este tipo de comunicaciones deben permanecer prácticamente inmunes a toda restricción ${ }^{17}$.

En este sentido, un importante sector doctrinal opina que no es posible intervenir las comunicaciones entre letrados y sus clientes salvo en supuestos excepcionalísimos (como cuando exista constancia de que el abogado, más allá del ejercicio del derecho de defensa, esté cometiendo un acto delictivo) ${ }^{18}$. Por su parte, el Tribunal Europeo de Derechos Humanos, teniendo en cuenta la naturaleza privilegiada de las comunicaciones que se producen entre un abogado y sus representados, considera que su intervención solo puede resultar de un juicio de proporcionalidad más estricto del que sería de aplicación a la intervención de cualquier otro tipo de comunicaciones ${ }^{19}$. Para este Tribunal, por tanto, es posible su restricción ${ }^{20}$, si bien siempre lo justifica atendiendo a las circunstancias extraordinarias del caso concreto. Eso sí, esta excepcionalísima medida exigirá una intensificación de los presupuestos a

${ }^{16}$ LÓPEZ YAGÜES, V., La inviolabilidad de las comunicaciones con el Abogado..., ob. cit.

${ }^{17}$ JIMÉNEZ CAMPO, J., "La igualdad jurídica como límite frente al legislador", $R e$ vista Española de Derecho Constitucional, núm. 9, 1987, p. 51; RODRÍGUEZ RUIZ, B., El secreto de las comunicaciones: tecnología e..., ob. cit., p. 123; LÓPEZ YAGÜES, V., La inviolabilidad de las comunicaciones con el Abogado..., ob. cit., pp. 375-376.

${ }^{18}$ VELASCO NÚÑEZ, E., "Presencias y ausencias (aspectos aclarados y discutidos) en materia de intervenciones telefónicas; en espera de una regulación parlamentaria del tema”, Revista de Actualidad Penal, núm. 18, 1993, p. 258; FERNÁNDEZ ESPINAR, G., "El levantamiento del secreto de las comunicaciones telefónicas en el marco de las diligencias de investigación y aseguramiento en el proceso penal", Poder Judicial, núm. 32, diciembre 1993, p. 27; LÓPEZ-BARAJAS PEREA, I., "La postulación y los derechos a la tutela y de defensa: la confidencialidad de las relaciones con el Abogado defensor y sus límites", Revista de Derecho Político, núm. 79, septiembre-diciembre 2010, pp. 127-128; LÓPEZ YAGÜES, V., La inviolabilidad de las comunicaciones con el Abogado..., ob. cit., pp. 66 y 211-212 (siguiendo a su vez a UBERTIS, A., Principi di Procedura Penale europea, Milano, p. 50). Esta autora recoge la doctrina comparada existente al respecto.

${ }^{19}$ Véase, al respecto, las SSTEDH de 15 de noviembre de 1996 (caso DOMENICHINI) y de 25 de marzo de 1998 (asunto KOPP).

${ }^{20}$ Así se ha admitido, entre otras, en sus sentencias de 30 se septiembre de 1985 (caso Can v. Austria, ; 20 de junio de 1988 (caso Schönenberger y Dumaz v. Suiza); 28 de noviembre de 1991 (caso S. v. Suiza); o 22 de abril de 2010 (caso Radkov v. Bulgaria). 
observar. En primer lugar, requerirá el refuerzo de la exigencia de indicios de criminalidad en la conducta que se imputa al Letrado, y, a continuación, una estricta motivación de la resolución judicial que decida la intromisión, expresiva de las circunstancias de las que deriva el indicio de participación en un delito de cierta entidad y el razonamiento que lleva a entender necesario el levantamiento del secreto ${ }^{21}$. Y todo esto, dicho con relación a la intervención de las comunicaciones abogados-clientes, resulta aplicable a las comunicaciones que tienen lugar entre los internos en establecimiento penitenciario con sus representantes legales (y con mayor motivo habida cuenta que la tutela de los derechos fundamentales de los sujetos privados de libertad debe ser especialmente rigurosa como consecuencia de la situación de subordinación en que los coloca la relación de sujeción especial que los vincula con la Administración ${ }^{22}$ ).

Pues bien, el debate sobre el alcance y los límites de la interceptación de las comunicaciones habidas entre los Abogados y sus clientes, y más particularmente, entre los Abogados y sus clientes internos en establecimiento penitenciario, ha recuperado protagonismo en nuestro país a raíz de las escuchas que autorizó el Magistrado del Juzgado Central de Instrucción núm. 5 de la Audiencia Nacional (D. Baltasar Garzón Real) de las comunicaciones producidas en el interior de la prisión de Soto del Real entre los imputados en el conocido como caso Gürtel y sus representantes legales.

21 "Si la medida consistente en la intervención de las comunicaciones debe tener siempre un carácter excepcional, en cuanto suspende el ejercicio del derecho fundamental a mantenerlas en secreto, cuando además concurra otro derecho fundamental como el derecho de defensa, parece claro que las garantías que deben rodear la injerencia deben ser extremadas. Se exigiría, por así decirlo, una "súper-excepcionalidad"”; LÓPEZ-BARAJAS PEREA, I., "La postulación y los derechos a la tutela y de defensa: la confidencialidad de las relaciones con el Abogado defensor y sus...", ob. cit., p. 124.

${ }^{22}$ En este sentido véase REVIRIEGO PICÓN, R. y BRAGE CAMAZANO, J., "Relaciones de sujeción especial e intervención de las comunicaciones entre los reclusos y sus letrados", Revista Europea de Derechos Fundamentales, núm. 16, segundo semestre 2010, pp. 141-167. Por otro lado, la propia sentencia de la Sala segunda del Tribunal Supremo de 9 de febrero de 2012, que ha motivado este escrito, señala que "Cuando los imputados se encuentran en situación de prisión preventiva, el ejercicio del derecho de defensa, mediante la relación con el letrado defensor solo puede tener lugar en el marco de la relación, calificada por una gran parte de la doctrina y la jurisprudencia (STC 2/1987) como de especial sujeción, que el interno mantiene con la Administración penitenciaria. De forma, que el imputado solo podrá comunicar personalmente con el letrado en los espacios habilitados en el centro penitenciario. Es cierto que esta situación ha sido utilizada como explicación para la restricción de los derechos del interno, incluso aun cuando tengan el carácter de fundamentales. Pero si se modifica la perspectiva y se examina la cuestión desde el punto de vista del titular de los derechos, en realidad supone una mayor responsabilidad de la Administración pública, en el caso la penitenciaria, que deberá velar porque solo se restrinjan los derechos del interno en la medida permitida por la ley, o como dice el art. 25.2 CE, por el contenido del fallo condenatorio, el sentido de la pena y la ley penitenciaria". 
Por Auto de fecha de 19 de febrero de 2009, este Magistrado, considerando que en la presunta actividad delictiva podían haber intervenido letrados y que los mismos podían estar aprovechando su condición de tales para actuar como "enlaces" de los imputados con el exterior, ordenó la observación de las comunicaciones personales que mantuvieran los internos Francisco Correa, Pablo Crespo y Antoine Sánchez con todos los letrados que se encontraban personados en la causa u otros que hubieran mantenido entrevistas con ellos, y con carácter especial, las que mantuvieran con el letrado D. José Antonio López Rubal, en el centro penitenciario en el que se encontraran o en cualquier otro al que fueran trasladados. La intervención se autorizó por un mes (del 19 de febrero al 20 de marzo de 2009). Posteriormente, por Auto de fecha de 20 de marzo de 2009, prorrogó todas las medidas acordadas en términos similares por un mes más (del 20 de marzo al 20 de abril de 2009). La única diferencia fue la omisión de toda mención al letrado D. José Antonio López Rubal, sustituido en los primeros días del mes de marzo por otro abogado, tras haber puesto de manifiesto el propio Juzgado a los imputados en prisión su posible incompatibilidad por la imputación del mismo en el caso (téngase en cuenta, además, que entre el primer auto judicial de autorización de dicha intervención y el segundo de prórroga fueron nombrados nuevos Abogados y que la medida también les afectó). Finalmente, por Auto de fecha de 27 de marzo de 2009, con el que pretendía salvar cualquier sospecha de ilicitud sobre esta intervención por vulneración del derecho de defensa, acordó excluir de la pieza las transcripciones entre los imputados y sus letrados que se hubieran referido exclusivamente a sus estrategias de defensa.

Precisamente, la vulneración del derecho fundamental a la defensa, con la consiguiente imposibilidad de tomar en consideración como prueba los resultados obtenidos, fue el argumento que llevó a la Sala de lo Civil y Penal del Tribunal Superior de Justicia de Madrid a declarar la ilicitud de las escuchas por Auto de fecha de 25 de marzo de $2010^{23}$. Además, el Magistrado Instructor que las autorizó ha sido sometido a una causa penal por prevaricación e intercepción ilegal de las comunicaciones que ha resuelto recientemente la Sala segunda del Tribunal Supremo en su sentencia de 9 de febrero de $2012^{24}$,

${ }^{23}$ La apelación contra las decisiones del juez Garzón se admitió por providencia de 28 de diciembre de 2009 y se resolvió favorablemente para los recurrentes por Auto de 25 de marzo de 2010 del Tribunal Superior de Justicia de Madrid (con el voto particular en contra del magistrado D. José Manuel Suárez Robledano).

${ }^{24}$ El Auto del Tribunal Supremo de 2 de febrero de 2010 admitió a trámite la querella presentada contra el Magistrado Instructor al que nos venimos refiriendo. Por su parte, el Auto de 13 de abril de 2010 desestimó el recurso de súplica que incoó el Ministerio Fiscal contra esta resolución, al que se adhirió la defensa del querellado, $\mathrm{y}$, por consiguiente, confirmó el Auto de admisión a trámite de la querella. El Auto de imputación, también del Tribunal Supremo, de 19 de octubre de 2010, se justifica por presuntos delitos de prevaricación y uso de artificios de escucha y grabación con violación de las garantías constitucionales. El Juez Instructor de esta causa, el Magistrado de la Sala segunda del Tribunal 
de la que ha sido ponente el Excelentísimo Señor D. Miguel Colmenero Menéndez de Luarca, y que ha concluido con la condena, por unanimidad, de D. Baltasar Garzón Real por un delito de prevaricación dolosa del artículo 446.3, en concurso aparente de normas con un delito del artículo 536, párrafo primero, que regula el delito cometido por funcionario público de uso de artificios de escucha y grabación, con violación de las garantías constitucionales, ambos del Código Penal.

La condena del Magistrado se basa, tanto en su falta de actuación secundum legem, es decir, en la ausencia de una cobertura legal previa en la que apoyar la medida, como en una adopción genérica de la misma en un contexto, además, de ausencia absoluta de indicios contra la mayoría de los letrados afectados. En todo caso, el intérprete supremo de la legalidad ordinaria considera especialmente trascendente, para condenar, esta absoluta falta de indicios cuando lo cierto es que la inexistencia de cobertura legal es causa suficiente para justificar una resolución de condena. De cualquier forma, no está de más que el Supremo recuerde en esta sentencia que una autorización judicial de intervención de las comunicaciones es una decisión tan relevante desde el punto de vista de la afectación sobre determinados derechos fundamentales que solo se puede adoptar cuando resulta absolutamente necesaria (por haber fracasado otros medios de investigación) y existan estos indicios.

\section{COMENTARIO A LA SENTENCIA DE LA SALA DE LO PENAL DEL TRIBUNAL SUPREMO DE 9 DE FEBRERO DE 2012}

\section{La afectación del derecho de defensa}

La sentencia de 9 de febrero de 2012 de la Sala segunda del Tribunal Supremo recoge, como hecho probado, que D. Baltasar Garzón tenía pleno conocimiento de la afectación que sus autorizaciones de intervención de estas comunicaciones estaban produciendo en el derecho de defensa (sobre el particular, especialmente, su fundamento jurídico segundo).

En efecto, que el entonces Magistrado era consciente de esta situación lo evidencia, no sólo el empleo de la fórmula "previniendo el derecho de defensa" que utiliza de forma insistente, o la exclusión de la pieza de las transcripciones entre los imputados y sus letrados que se hubieran referido exclusivamente a sus estrategias de defensa que incorpora en el último de sus Autos, sino también que debiera pronunciarse y ratificarse, en diversas oca-

Supremo, D. Alberto Jorge Barreiro, acordó la apertura del juicio oral contra el acusado por Auto de fecha de 2 de abril de 2011. El Ministerio Fiscal interesó que se dictara Auto de sobreseimiento libre por no estimar la existencia de delito. Las acusaciones particulares en nombre de D. Ignacio Peláez, D. Francisco Correa y D. Pablo Crespo entendieron que se había incurrido en los delitos recogidos en los artículos 446.3 y 536.1 del Código Penal y solicitaron la condena. 
siones, sobre la intervención de las comunicaciones que tenían lugar entre los internos en establecimiento penitenciario afectados por la medida y sus representantes legales. En este sentido, cuando la Dirección General de Instituciones Penitenciarias recibió comunicación de su primer Auto de 19 de febrero de 2009 sobre su grabación, solicitó aclaración respecto a si las comunicaciones con los letrados, a las que se hacía referencia en el Auto, debían ser grabadas (esto es, la propia dirección penitenciaria detectó ya, desde el inicio, la problemática que planteaba la autorización judicial y solicitó la confirmación del juez al respecto). A ello contestó afirmativamente D. Baltasar Garzón. Por su parte, los funcionarios policiales le solicitaron una aclaración sobre cómo había de procederse al efecto de hacer efectiva la cláusula "previniendo el derecho de defensa", a lo que se contestó que habían de limitarse a recoger las cintas, escuchar lo grabado, transcribir todo su contenido excluyendo las conversaciones privadas sin interés para la investigación y proceder a su entrega en el juzgado, ocupándose el propio Magistrado de lo que procediera en orden al cumplimiento de dicha cláusula.

De nuevo, el derecho de defensa se invoca con ocasión de la solicitud de la prórroga de la medida. Esta vez por parte del Ministerio Fiscal, que en su informe no se opone a la prórroga siempre y cuando se decida "con expresa exclusión de las comunicaciones mantenidas con los letrados que representan a cada uno de los imputados, $\mathrm{y}$, en todo caso, con rigurosa salvaguarda del derecho de defensa"25. Con este informe del Fiscal, D. Baltasar Garzón acordó la prórroga por Auto de 20 de marzo de 2009 sin añadir, como el propio Tribunal Supremo se encarga de señalar, cautela especial alguna para la salvaguarda del derecho de defensa, más allá de la persistencia en la utilización de la cláusula "previniendo el derecho de defensa". Una vez autorizada la prórroga, el Ministerio Fiscal vuelve a emitir un informe en el que reitera el contenido del anterior "e interesa, con la misma finalidad, que, en lo sucesivo se excluyan de la causa todas aquellas comunicaciones que se refieren exclusivamente al ejercicio del derecho de defensa de aquellos". Dicho informe fue el que dio lugar a un nuevo Auto con fecha de 27 de marzo de 2009, en el que disponía "excluir de esta pieza las transcripciones de las conversaciones mantenidas entre los imputados Francisco Correa Sánchez, Pablo Crespo Sabaris y Antoine Sánchez y sus letrados y que se refieran en exclusiva a sus estrategias de defensa". En cumplimiento de lo dispuesto, el funcionario encargado de la tramitación de la causa, por orden verbal del Magistrado, que le comunicó que siguiera las indicaciones de uno de los representantes del Ministerio Fiscal en la causa que en ese momento se encontraba en las dependencias del juzgado, procedió, según éste le indicó, a suprimir distintos párrafos de las

${ }^{25}$ En concreto, el Fiscal afirma que una parte importante de las transcripciones se refieren en exclusiva a las estrategias de defensa, y, por tanto, deben ser excluidas del procedimiento (enumera, en concreto, las conversaciones que deben desglosarse necesariamente de la causa). 
transcripciones de las conversaciones mantenidas por los internos y sus abogados defensores en los locutorios de la prisión.

Es evidente, por otra parte, que la confidencialidad de la relación existente entre los representantes legales y sus clientes, instrumental respecto del derecho de defensa, es presupuesto para la existencia de un proceso contradictorio y equitativo (esto es, caracterizado por el principio de igualdad de armas $)^{26}$. En el proceso inquisitivo, la posición del presunto culpable aparece completamente subordinada al rol preponderante de la acusación (por ello se dice que nos encontramos realmente ante un objeto del proceso y no ante un auténtico sujeto del mismo), y, en consecuencia, el papel de la defensa se presenta como absolutamente irrelevante, o peor todavía, como un obstáculo para la buena marcha del juicio. El modelo procesal acusatorio (o cognoscitivo o garantista como también lo ha denominado FERRAJOLI ${ }^{27}$ ), o el modelo procesal mixto que finalmente fue el que se impuso en la Francia napoleónica, y, desde allí, en el resto de Europa, podrían definirse -si bien más el primeropor oposición al sistema inquisitivo. En ambos supuestos (acusatorio puro y mixto), la relación entre la acusación y el acusado sufre una transformación cualitativa ya que se consagra el principio de la presunción de inocencia colocando así al acusado al mismo nivel que la acusación. A partir de este momento, ambos, acusación y acusado, actúan en el mismo plano, y, por consiguiente, el principio de igualdad de armas ha de regir su acción durante un proceso contradictorio que se desarrolla sobre la base de las pruebas que aporta la acusación y la consiguiente refutación de las mismas procedente de

\footnotetext{
${ }^{26}$ En la sentencia del TEDH de 5 de octubre de 2006, caso Viola contra Italia (61), se decía que "...el derecho, para el acusado, de comunicar con su abogado sin ser oído por terceras personas figura entre las exigencias elementales del proceso equitativo en una sociedad democrática y deriva del artículo $6.3 \mathrm{c}$ ) del Convenio. Si un abogado no pudiese entrevistarse con su cliente sin tal vigilancia y recibir de él instrucciones confidenciales, su asistencia perdería mucha de su utilidad (Sentencia S. contra Suiza de 2 de noviembre de 1991, serie A núm. 220, pág. 61, ap. 48)”. Igualmente, sobre la confidencialidad de las relaciones entre el imputado defensor y su letrado defensor como elemento esencial del proceso pueden consultarse las sentencias del TEDH Castravet contra Moldavia, de 13 de marzo de 2007; y Foxley contra Reino Unido, de 20 de junio de 2000.

${ }^{27}$ FERRAJOLI, L., Derecho y razón. Teoría del garantismo penal, ed. Trotta, Madrid, 2004, pp. 566-567. En el caso que venimos analizando, el Tribunal Supremo recuerda además, con relación al Instructor en un proceso penal, a quien compete la dirección de la investigación, que "no le corresponde ocupar una posición propia o característica de un enemigo del investigado, estando, por el contrario, obligado a "....consignar y apreciar las circunstancias así adversas como favorables al presunto reo..." (artículo 2 LECrim). Además, resulta encargado de la protección de los derechos fundamentales del imputado, en tanto que la Constitución, ordinariamente, condiciona su restricción a la existencia de una resolución judicial debidamente motivada. Por lo tanto, en ningún caso su responsabilidad resultaría mermada por el hecho de que la medida le hubiera sido solicitada. De todos modos, el acusado asumió haber dictado los autos de 19 de febrero y de 20 de marzo como una decisión propia".
} 
la defensa. Ello exigirá, naturalmente, ya lo hemos anticipado, que se respete la confidencialidad de las relaciones de los Abogados con sus representantes, $\mathrm{y}$, a su través, el derecho de defensa ${ }^{28}$. Como señala el Supremo en esta sentencia de 9 de febrero de 2012, resulta fácil entender que si los responsables de la investigación conocen o pueden conocer el contenido de estas conversaciones, la defensa pierde gran parte de su eficacia. A ello abría que añadir el efecto disuasorio (chilling effect) que podría generar la legitimación de este tipo de actuaciones judiciales de intervención de las comunicaciones de los abogados con sus representados (ya que sus conversaciones -orales y/o escritas- para diseñar la estrategia de defensa no podrán fluir libremente con la sospecha de que su interceptación se puede producir en cualquier momento y no, única y exclusivamente, en supuestos extraordinarios).

El intérprete supremo de la legalidad ordinaria nos recuerda, igualmente, en el fundamento jurídico preliminar de esta misma resolución, que "el derecho de defensa es un elemento nuclear en la configuración del proceso penal del Estado de Derecho como un proceso con todas las garantías" y que "no es posible construir un proceso justo si se elimina esencialmente el derecho de defensa, de forma que las posibles restricciones deben estar especialmente justificadas"29 (ya hemos visto cómo los bienes y derechos constitucionales que se encuentran en juego en este caso exigen del órgano juzgador competente para decidir al respecto una especial dosis de rigurosidad en cuanto al cumplimiento de los requisitos exigidos para adoptar la medida $)^{30}$. A su juicio, la conducta de D. Baltasar Garzón ha causado "una drástica e injustificada reducción del derecho de defensa y demás derechos afectados anejos al mismo", y, de forma contundente, lapidaria, afirma que su actuación ha colocado al "proceso penal español, teóricamente dotado de las garantías constitucionales y legales propias de un Estado de Derecho contemporáneo, al nivel de sistemas políticos y procesales característicos de tiempos ya superados desde la consagración y aceptación generalizada del proceso penal liberal moderno, admitiendo prácticas que en los tiempos actuales solo se encuentran en los regímenes totalitarios en los que todo se considera válido para obtener la información que interesa, o se supone que interesa, al Estado, prescindiendo de las mínimas garantías efectivas para

${ }^{28}$ Sobre el derecho de defensa como principio fundamental de la Unión puede verse la sentencia de la Gran Sala del Tribunal de Justicia de las Comunidades Europeas de 14 de septiembre de 2010 (caso Azko y Akcros/Comisión).

${ }^{29}$ La cursiva es añadida.

${ }^{30}$ En las conversaciones entre letrados-clientes no sólo está en juego la comunicación libre entre las personas, sino también la comunicación para preparar la defensa. Por ello, el TEDH ha reconocido, como algo imperativo para los Estados, un "estatuto privilegiado" para tales comunicaciones (por ejemplo, sentencia del TEDH de 30 de enero de 2007, caso Erincy y Akalin c. Turquía); REVIRIEGO PICÓN, R. y BRAGE CAMAZANO, J., "Relaciones de sujeción especial e intervención de las comunicaciones entre los reclusos y sus...", ob. cit., p. 69. 
los ciudadanos y convirtiendo de esta forma las previsiones constitucionales y legales sobre el particular en meras proclamaciones vacías de contenido" (en el fundamento jurídico décimo-segundo, apartado cuarto). Por otro lado, la actuación del D. Baltasar Garzón, también habría lesionado, según el Supremo (en breve pasaremos a desgranar sus argumentos), derechos tales como el derecho a no auto incriminarse o a no declarar contra uno mismo, la intimidad y el secreto profesional.

En cuanto al empleo de la expresión "previniendo el derecho de defensa" que utiliza insistentemente D. Baltasar Garzón Real, el Tribunal entiende que de ella no se desprende una verdadera intención de prevenir el derecho de defensa y la califica como una cláusula meramente formal. Tampoco podría valorarse como protección del derecho de defensa la supresión de algunos párrafos de las conversaciones una vez que han sido escuchadas por los funcionarios policiales responsables de la investigación, los cuales, añade, ni siquiera fueron requeridos para que no las utilizaran en sus informes $o$ conclusiones o líneas de investigación ${ }^{31}$. Y es que, "no es preciso (...) que aparezca un aprovechamiento expreso mediante una acción concreta y directamente relacionada con lo indebidamente sabido, pues basta para lesionar el derecho de defensa con la ventaja que supone para el investigador la posibilidad de saber (y con mayor razón el conocimiento efectivo), si el imputado ha participado o no en el hecho del que se le acusa, saber si una línea de investigación es acertada o resulta poco útil, saber cuál es la estrategia defensiva, cuáles con las pruebas contrarias a las de cargo, o incluso conocer las impresiones, las necesidades o las preocupaciones del imputado, o los consejos y sugerencias que le hace su propio letrado defensor. Se trata de aprovechamientos más sutiles, pero no por eso inexistentes ${ }^{32}$. Basta, pues, con la escucha, ya que desde ese momento se violenta la confidencialidad, elemento esencial de la defensa"33.

${ }^{31}$ El Supremo continúa afirmando, en su FJ $10^{\circ}$, que dicha supresión únicamente cobraría sentido en los supuestos en los que, como consecuencia de una intervención de las comunicaciones, se intervienen accidentalmente conversiones entre los letrados y sus clientes relativas a la estrategia de defensa. Sensu contrario, la supresión no puede ser considerada en relación con una resolución orientada directamente al conocimiento del contenido de tales comunicaciones, pues la exclusión solo puede producirse una vez oídas las conversaciones y desde ese momento el investigador ya conoce el contenido de lo hablado.

${ }^{32}$ Así afirma que "una vez que la policía, el juez instructor y el fiscal del caso oyen las conversaciones entre el imputado y su letrado defensor, la exclusión de las mismas de la causa sólo evitan su utilización como prueba, pero no su empleo, expreso o tácito durante la investigación en la fase de instrucción".

${ }^{33}$ El Tribunal Supremo recoge inmediatamente después la doctrina del Tribunal Europeo de Derecho Humanos al respecto. En concreto, este Tribunal ha señalado que la injerencia existe desde la interceptación de las comunicaciones sin que importe la posterior utilización de las grabaciones (STEDH de 25 de marzo de 1998, asunto Kopp contra Suiza). 


\section{La condena por prevaricación de D. Baltasar Garzón en el caso Gürtel}

\subsection{Consideraciones preliminares sobre la exigencia de responsabilidad penal del juzgador por el ejercicio de la función jurisdiccional}

La sujeción del juez a criterios de racionalidad en el momento de la valoración de la prueba y al ordenamiento jurídico en la resolución del conflicto jurídico no es solo un deber constitucional. También es un elemento imprescindible para aportar legitimidad a su actividad. Por tanto, el juez es responsable por la aplicación del Derecho, y debe responder también por una valoración correcta, racional, de la prueba. Brevemente, podríamos decir que la actuación judicial ajena a criterios de racionalidad y/o al ordenamiento jurídico debe generar, en línea de principio, la responsabilidad del juzgador.

Ahora bien, esta última afirmación plantea interrogantes desde el momento en que se acepta-como es nuestro caso- la tesis de la discrecionalidad judicial ${ }^{34}$. Si admitimos que no es posible mantener el sistema deductivo de valoración de la prueba, esto es, aquél que proporciona una certeza absoluta si se ha partido de la premisa correcta, ni la existencia de una actividad silogista-mecanicista de la interpretación y aplicación de la norma; si admitimos que resulta posible hablar de varias soluciones fácticas e interpretativas aplicables a un mismo supuesto jurídico (que no existe, por tanto, la unidad de solución correcta), entonces... ¿qué otra cosa hacer sino reconocer que existen límites a la exigencia de la responsabilidad judicial?

La valoración de la prueba y la interpretación del Derecho ofrecen márgenes de discrecionalidad al juzgador y su elección, amparada por el principio de la independencia judicial, si bien opinable, no puede ser, a priori, calificada como una inobservancia de los deberes del cargo. Además, esta discrecionalidad de la que "disfrutan" jueces y magistrados para valorar los resultados fácticos y aplicar el Derecho hace realmente complicada la tarea de discernir dónde están los límites a partir de cuya trasgresión se podrá aludir a una responsabilidad de los mismos por incumplimiento de su función, si bien no es posible plantear ninguna objeción a la tesis según la cual, sobrepasados determinados límites lógicos en la actividad valorativa e interpretativa que realizan, la responsabilidad se concilia con el principio de la independencia judicial ${ }^{35}$. En este sentido, el Tribunal Supremo acaba de volver a recordarnos, en su sentencia de 9 de febrero de 2012 y

${ }^{34}$ Sobre la naturaleza híbrida de la función jurisdiccional, normativa y descriptiva, MARTÍNEZ ALARCÓN, Ma L., "La aplicación judicial del Derecho constitucional”, Teoría y Realidad Constitucional, núm. 21, 2008.

${ }^{35}$ En este sentido FASSONE, E., "Il giudice tra independenza e responsabilità", Rivista Italiana di Diritto e Procedura Penale, I, 1980, p. 24. En un sentido absolutamente contrario, con una tesis que no podemos compartir, véase GIACOBBE, G., "La responsabilità del giudice: A propósito di una recenté proposta di legge", In Iure Praesentia, 1980, pp. 27-32. Considera que hay soberanía en los órganos que ejercen las funciones del Estado (¿una soberanía más allá del pueblo?) y esto le permite excluir cualquier tipo de responsabilidad 
con relación a la actuación judicial secundum legem, que "En un sistema democrático como el regulado en la Constitución española, el Poder Judicial se legitima por la aplicación de la ley a la que está sujeto, y no por la simple imposición de sus potestades. De manera que el Estado de Derecho se vulnera cuando el juez, con el pretexto de la aplicación de la ley, actúa solo su propia subjetividad concretada en una forma particular de entender la cuestión a resolver, y prescindiendo de todos los métodos de interpretación admisibles en derecho, acoge un significado irracional de la norma, sustituyendo así el imperio de la ley por un acto contrario de mero voluntarismo (...). Desde esta perspectiva, la previsión legal del tipo de prevaricación no puede ser entendida en ningún caso como un ataque a la independencia del Juez (...)". Eso sí, para no incidir negativamente en el principio de independencia judicial, solo será posible reclamar responsabilidad al juez cuando su alejamiento de una correcta valoración de la prueba o de una aplicación de la norma se produce mediando dolo o, cuando menos, culpa grave, esto es, cuando se constata la falta siquiera de una mínima diligencia en el actuar del juzgador que le hubiera podido llevar a uno de los posibles resultados ofrecidos por el ordenamiento jurídico o a una valoración de la prueba apoyada en algún criterio de racionalidad. La existencia de este tipo de culpa dependerá, naturalmente, del grado con el que la decisión aparezca predeterminada por las normas aplicables al caso y de la claridad del material probatorio. A efectos penales, por tanto, sólo podrán tomarse en consideración las interpretaciones imposibles del ordenamiento jurídico ${ }^{36} \mathrm{y}$ los resultados probatorios manifiestamente improbables.

En este sentido, como veremos al analizar el elemento objetivo del ilícito recogido en el artículo 446 del Código penal, la jurisprudencia -también la doctrina mayoritaria- suelen exigir que la contradicción objetiva con el ordenamiento jurídico sea patente y evidente, a pesar de que dicho precepto no emplea un adverbio del tipo "manifiestamente" (lo mismo cabría señalar sobre la necesidad de una evidente irracionalidad en el resultado de la valoración de la prueba ${ }^{37}$ ). A nuestro juicio no cabe otra

por el contenido del ejercicio de la función jurisdiccional, incluso en los casos patológicos de macroscópicas violaciones. Por otro lado, sobre el entendimiento complementario de las categorías de la independencia y la responsabilidad judicial, puede consultarse MARTÍNEZ ALARCÓN, Ma L., La independencia judicial, CEPC, Madrid, 2004, p. 327 y ss.

${ }^{36}$ QUINTERO OLIVARES, G. (dir.) y MORALES PRATS, F. (coord.), Comentarios a la Parte Especial del Derecho del Derecho Penal, 20 ed., ed. Aranzadi, Pamplona 1999, p.1319; CUELLO CONTRERAS, J., "Jurisprudencia y prevaricación", RJELL, 1-1993, p. 1042. En sentido contrario, con una interpretación que no compartimos, véase SERRANO BUTRAGUEÑO, I. (coord..), Código Penal de 1995. (Comentarios y jurisprudencia), Granada 1999, p. 1763; BELLO LANDROVE, F., "Los elementos de injusticia y manifiesta injusticia en el delito de prevaricación en el Código Penal español”, Revista General de Legislación y Jurisprudencia, 1977, p. 254.

${ }^{37}$ GARCÍA ARÁN, M., La prevaricación..., ob. cit., p. 120. Por su parte, el artículo $447 \mathrm{CP}$ sanciona con la pena de inhabilitación especial para empleo o cargo público por 
alternativa. Las diversas posibilidades interpretativas que ofrece el ordenamiento jurídico y las diversas posibilidades valorativas que ofrecen las pruebas y la independencia del juez para optar por la que considere más correcta, unido a la creciente complejidad del material probatorio y del sistema normativo, nos obligan a admitir la tesis de que solo en los casos de palmaria ilegalidad e irracionalidad, cuando la decisión judicial no es justificable de ninguna forma, y además, se produce mediante dolo, estamos ante la prevaricación prevista en el artículo 446 del Código penal. Esto es, para sancionar por prevaricación es preciso que no exista ningún argumento racional o jurídico razonable para sustentar la decisión. Y recordemos que D. Baltasar Garzón ha sido condenado por el delito recogido en el artículo 446.3 del Código penal, el cual dispone que "El juez o magistrado que, a sabiendas, dictare sentencia o resolución injusta será castigado: (...) $3^{\circ}$. Con la pena de multa de doce a veinticuatro meses e inhabilitación especial para empleo o cargo público por tiempo de diez a veinte años, cuando dictare cualquier otra sentencia o resolución injusta".

\subsection{El elemento objetivo del ilícito: La ausencia de una conducta racional y secundum legem}

En el ordenamiento jurídico español, el único tipo penal que sanciona comportamientos que son fruto de un incorrecto ejercicio del qué de la función jurisdiccional, es el de prevaricación (sólo en este supuesto estamos ante infracciones delictivas del deber de decidir de forma imparcial y secundum legem y del deber de utilizar parámetros racionales en el examen del material probatorio ${ }^{38}$. Con relación al juicio secundum legem, la sentencia del Tribunal Supremo de 15 de octubre de 1999, fundamento jurídico tercero a) ${ }^{39}$, señalaba que "El delito de prevaricación no consiste en la lesión de bienes jurídicos individuales de las partes en el proceso, sino en la postergación por el autor de la validez del derecho o de su imperio y, por lo tanto, en la vulneración del Estado de Derecho"40.

tiempo de dos a seis años al juez o magistrado que por imprudencia grave o ignorancia inexcusable dictara sentencia o resolución manifiestamente injusta. Así pues, solo en aquellos supuestos en los que ha existido una macroscópica violación del ordenamiento jurídico y de la racionalidad en el juicio probatorio y respecto de los cuales, por tanto, una mínima diligencia por parte del operador jurídico hubiera bastado para salvar el error, es posible sancionar penalmente al operador jurídico.

${ }^{38}$ Como señala la profesora GARCÍA ARÁN, el análisis del bien jurídico debe partir del estudio de las funciones del Estado en nuestro marco constitucional, y, si bien es cierto que con anterioridad a la aprobación de la Constitución española de 1978 primaba la condición funcionarial del sujeto activo del tipo sobre la dimensión objetiva de la función que prestaba lo que desembocaba, finalmente, en situar el bien jurídico protegido de este delito en la relación funcionarial entre el Estado y el juez, lo cierto es que hoy se destaca como contenido esencial del ilícito penal la lesión de la función, GARCÍA ARÁN, M., La prevaricación judicial, ed. Tecnos, Madrid, 1990, pp. 39, 446-48, 55.

${ }^{39}$ RJ 1999, 7176. 
Por consiguiente, el concepto de injusticia del ilícito de prevaricación recogido en el artículo 446 del Código Penal (la acción de dictar resolución injusta), "se determina objetivamente confrontando la resolución con el ordenamiento [y con criterios de racionalidad en el momento probatorio] y careciendo de relevancia si el juez resuelve o no contra su conciencia o su personal concepto de justicia supralegal". La teoría subjetiva según la cual se produce prevaricación cuando el juez resuelve contra su propia convicción y que, por tanto, permite resolver al juzgador conforme a conciencia y en contra de la ley o de cualquier canon de racionalidad sin prevaricar, desemboca en la inexistencia de la vinculación a la ley y a determinados criterios de racionalidad y es incompatible con el bien jurídico que pretende proteger el tipo penal ${ }^{41}$. Por lo demás, la interpretación objetiva del ilícito, y la consiguiente negación de su interpretación subjetiva, es la que defiende nuestro Tribunal Supremo. La sentencia de la Sala segunda de este órgano judicial, de fecha 9 de febrero de 2012, señala que la configuración del elemento del tipo objetivo, "viene a rechazar al mismo tiempo la teoría subjetiva de la prevaricación, según la cual se apreciaría delito poniendo el acento en la actitud o en la convicción del juez al resolver, y prescindiendo de que la resolución sea objetivamente conforme a la ley". Desde este punto de vista, es evidente que “... la injusticia objetiva de la resolución no puede ser eliminada recurriendo a la subjetividad del autor, dado que el Juez debe aplicar el derecho y no obrar según su propia idea de justicia (STS 2/1999). Por lo tanto, no puede admitirse que una resolución sea justa solo porque el juez que la dicta, sin referencia alguna a criterios objetivos, así la considere" $"$.

${ }^{40}$ En el fundamento jurídico tercero d) de esta misma resolución además se afirmaba que el quebrantamiento del Derecho es de mayor gravedad atendiendo a la jerarquía del derecho vulnerado (es muy discutible el empleo del concepto de jerarquía al hablar de derechos) y a la importancia de las consecuencias de la infracción para los derechos fundamentales de las partes. Por otra parte, sujeto activo de la conducta son los jueces y magistrados, no siendo necesario que éstos pertenezcan a la carrera judicial (el dato básico para que el delito se cometa es que estén realizando funciones jurisdiccionales). Y, a diferencia de lo que sucedía en la regulación anterior, actualmente no ofrece duda alguna el hecho de que las decisiones injustas se sancionan todas independientemente de su clase (se sancionan, por tanto, las sentencias, autos y providencias injustos).

${ }^{41}$ Conforme a la teoría subjetiva, "la vinculación con la ley es prácticamente inexistente, el juez está obligado, no a la aplicación de la misma, sino a la realización de un concepto metalegal de justicia que ni siquiera debe ser constatable objetivamente, sino que se sitúa en su propia conciencia. Además de concebir este delito como una mera actitud interna, lo cual ya es criticable, supone partir de la idea de que la aplicación del Derecho es una suerte de magma indescifrable ante el que los jueces no deben sino seguir sus impulsos anímicos para hacer justicia"; GARCÍA ARÁN, M., La prevaricación..., ob. cit., pp. 107-108. Véase, igualmente, LÓPEZ GARRIDO, D. y GARCÍA ARÁN, M., El Código Penal de 1995 y la voluntad del legislador. Comentario al texto y debate parlamentario, ed. Eujuris, Madrid, 1996, p. 187; CUELLO CONTRERAS, J., “Jurisprudencia y...”, ob. cit., pp. 1045 y 1048.

${ }^{42}$ En jurisprudencia anterior: "El delito de prevaricación judicial se comete cuando un Juez o Magistrado, a sabiendas, dictare una resolución injusta, en el sentido de contraria a 
Por otro lado, a efectos penales, y tal y como ha vuelto a recordar esta misma resolución, en su fundamento jurídico $5^{\circ} .2$, "la jurisprudencia (...) ha venido insistiendo en que la injusticia requerida por el artículo 446 del Código vigente exige una absoluta colisión de la actuación judicial con la norma aplicada en el caso, de tal forma que la decisión cuestionada no pueda ser explicada mediante ninguna interpretación razonable efectuada con los métodos admitidos en Derecho", y que, en definitiva, "se entenderá por resolución injusta aquella que se aparta de todas las opciones jurídicamente defendibles según los métodos usualmente admitidos en Derecho, careciendo de toda interpretación razonable, y siendo en definitiva exponente de una clara irracionalidad"43. "Naturalmente se podrá discutir si en un caso concreto es más adecuada una interpretación teleológica que otra gramatical, lo que no es discutible es que las decisiones basadas en la propia convicción empecinada del juez, sin fundamento racional en la ley, son incompatibles con el Estado democrático de Derecho (art. 1 de la Constitución Española)" ${ }^{44}$.

Derecho, y sin que para valorar penalmente esa conducta proceda tener en cuenta los designios, propósitos o intenciones que le hubieran guiado al realizarla"; ATS de 16 de junio de 1998, FJ primero (RJ 1998\5377). "La injusticia objetiva de la resolución no puede ser eliminada recurriendo a la subjetividad del autor, dado que el Juez debe aplicar el derecho, no obrar según su propia idea de la Justicia"; STS de 15 de octubre de 1999, fundamento jurídico tercero b) (RJ 1999 17176). Igualmente, en la STS 2338/2001 se decía: "En relación al elemento objetivo de la resolución injusta, una vez más, debemos afirmar con la constante jurisprudencia de esta Sala, por otra parte no muy numerosa, de la que son exponente las STS de 14 de febrero de 1891, 21 de enero de 1901, 1/1996, de 4 de julio, en Causa Especial 2830/1994, 155/1007 y la última, más completa y reciente la 2/1999, de 15 de octubre en Causa Especial 2940/1997, que la determinación de tal injusticia no radica en que el autor la estime como tal, sino que en clave estrictamente objetiva la misma merezca tal calificación cuando la resolución no se encuentra dentro de las opiniones que puedan ser jurídicamente defendibles". Recordemos, por otro lado, que D. Baltasar Garzón alegó durante el proceso penal que su conducta venía motivada, no tanto porque entendiera que detrás de la misma había una cobertura legal que la respaldara, sino por su intención de luchar de forma efectiva contra la posible comisión de delitos.

${ }^{43}$ La sentencia del Tribunal Supremo de 9 de febrero de 2012 se remite en estos momentos a la STS 2/1999, en la que se decía que el apartamiento del Derecho “... será de apreciar, por lo general, cuando la aplicación del derecho no resulte de ningún método o modo aceptable de interpretación del derecho".

${ }^{44}$ STS de 15 de octubre de 1999, fundamento jurídico tercero d) sobre cuestiones de fondo (RJ 1999\7176). Igualmente, la sentencia del Tribunal Supremo de 4 de julio de 1996, reclama, para que se produzca este tipo penal, una flagrante ilegalidad que ponga de manifiesto la indudable irracionalidad de la resolución de que se trate. En parecidos términos véase las SSTS de 26 de marzo de 1992 (RJ 1992\2475); de 10 de abril de 1992 (RJ 1992\2954); de 25 de marzo de 1995 (RJ 1995\2236); de 10 de julio de 1995 (RJ 1995\5400); 257/1997 (RJ 1997\1822; 61/1998, de 27 de enero (RJ 1998\98); 1417/1998 (RJ 1998\10402). No toda infracción de normas legales acarrea la responsabilidad criminal, dado que el elemento del tipo penal es la resolución injusta, no la simple resolución ilegal"; STS de 18 de junio de 1992 (RJ 1992\5961) y ATS de 14 de julio de 1999 (RJ 1999\7363). "La revocación de resoluciones a los Jueces por sus superiores funcionales no implica `per se' conducta prevaricadora de aquellos"; STS de 26 de marzo de 1998 (RJ 1998\2426). 
Pues bien, en el caso que venimos analizando, la sentencia del Supremo de 9 de febrero de 2012 concluye que resulta absolutamente evidente cuál es la norma aplicable al supuesto fáctico así como su interpretación (que resulta de la jurisprudencia del Tribunal Constitucional asumida -como no podía ser de otra forma habida cuenta su naturaleza de fuente del Derecho- también por el intérprete supremo de la legalidad ordinaria).

Con relación a la primera cuestión, el Tribunal Supremo ha concluido que la norma aplicable sería el precepto especial recogido en el artículo 51, párrafo segundo de la Ley Orgánica General Penitenciaria, el único que -coincidimos con el órgano judicial-se refiere a los límites de la confidencialidad de las comunicaciones de los presos con sus letrados cuando establece que "Las comunicaciones de los internos con el Abogado defensor o con el Abogado expresamente llamado en relación con asuntos penales y los Procuradores que los representen, se celebrarán en departamentos apropiados y no podrán ser suspendidas o intervenidas salvo por orden de la autoridad judicial $\mathrm{y}$ en los supuestos de terrorismo"45.

En efecto, la interpretación según la cual resultaría plausible considerar que el artículo 51.2 de la Ley Penitenciaria se refiere a medidas de régimen penitenciario permitiendo así la intervención de este tipo de comunicaciones por razones de seguridad y buen orden del establecimiento penitenciario o el interés del tratamiento, mientras que el artículo 579 de la Ley de Enjuiciamiento Criminal tendría como ámbito de aplicación las medidas de investigación sumariales ${ }^{46}$, resulta inviable a la luz de la interpretación que el

${ }^{45}$ La STC 58/1998, de 16 de marzo, FJ 50, establece que "el sistema de garantías reforzado para la intervención del artículo 51.2 de la LOGP comprende las comunicaciones escritas, del tipo que sean, entre preso y Abogado, y que la alusión de dicho apartado a la celebración en departamentos apropiados no supone una exclusión de las comunicaciones escritas, sino una mera especificación del modo en el que deben celebrarse las orales".

${ }^{46}$ La opción por un precepto u otro (art. 51.2 LOGP o 579 LECrim) no resulta inocua pues, en efecto, parece que la aplicación del artículo referido del código procesal criminal podría ofrecer cobertura legal a una actuación judicial de estas características (intervención de las comunicaciones entre Abogados y clientes más allá, incluso, de los delitos de terrorismo). En concreto, el Ministerio Fiscal recurrió a la aplicación de este precepto para justificar los Autos de D. Baltasar Garzón, tanto ante el Tribunal Superior de Justicia de Madrid, como ante el propio Tribunal Supremo. Por otra parte, los Autos del Magistrado Instructor que decidieron la intervención de estas comunicaciones, y su prórroga, aludían exclusivamente al artículo 51.2 de la Ley Penitenciaria y en ningún caso al artículo 579 LECrim. Sólo posteriormente, reproduciendo la tesis mantenida por el Ministerio Fiscal, y, probablemente, convencido de la dificultad para justificar su actuación con base en la Ley penitenciaria según jurisprudencia del Tribunal Constitucional, alega la aplicación del precepto del Código procesal criminal. Por otra parte, el Auto de imputación del Tribunal Supremo de 19 de octubre de 2010 también defiende la aplicación del artículo 579 LECrim (que, según dicho auto, podría haber servido de cobertura a la actuación de D. Baltasar Garzón si no hubiera sido porque ésta se produjo en un contexto de ausencia absoluta de indicios). No es ésta, por cierto, la tesis que finalmente recoge el Tribunal Supremo en la 
Tribunal Constitucional ha hecho del artículo 51.2 del texto penitenciario cuando ha sostenido, en su sentencia 183/1994, de 20 de junio ${ }^{47}$, que el único fin que justifica las escuchas de las comunicaciones habidas entre los internos en establecimiento penitenciario con sus representantes legales es la persecución del delito y no, por tanto, la seguridad y buen orden del establecimiento penitenciario o el interés del tratamiento ${ }^{48}$.

Por otra parte, la interpretación constitucional consolidada de la norma aplicable al caso, asimismo asumida por el Tribunal Supremo ${ }^{49}$, excluía de raíz su utilización a un caso como el que se planteaba en esta ocasión. Según el Tribunal Constitucional, los dos presupuestos recogidos en el artículo 51.2 de la Ley Penitenciaria (orden de la autoridad judicial y supuestos de terrorismo) funcionan, a efectos de autorizar la intervención de las comunicaciones de los internos en establecimiento penitenciario con sus representantes legales, como condiciones acumulativas (no alternativas). En concreto, en su sentencia 183/1994, de 20 de junio, corrigiendo una decisión propia anterior ${ }^{50}$, considera

sentencia de condena del acusado de 9 de febrero de 2012. Un análisis detenido y una crítica del Auto de imputación del Supremo de 19 de octubre de 2010 en REVIRIERO PICÓN, F. y BRAGE CAMAZANO, J., "Relación de sujeción especial e intervención de las comunicaciones entre los reclusos y sus...", ob. cit., pp. 80-86.

${ }^{47}$ En el mismo sentido véase la sentencia del Tribunal Supremo 538/1997, de 23 de abril o la propia sentencia de este mismo órgano judicial de 9 de febrero de 2012, FJ $8^{\circ}$. Asimismo, un sector muy numeroso de la doctrina constitucional española. A saber: MARTÍNEZ ESCAMILLA, M., La suspensión e intervención de las comunicaciones del..., ob. cit., pp. 133-140; GARCÍA VALDÉS, C., Comentarios a la legislación penitenciaria, $2^{\text {a }}$ ed. ed. Cívitas, Madrid, 1982, p 175; MARCHENA GÓMEZ, M., "La injerencia de la Administración Penitenciaria en las comunicaciones del interno con su abogado. (A propósito del Auto de la Audiencia Nacional de 20-12-1993)", Anuario de Derecho Penal y Ciencias Penales, t. 47, 1994, p. 34.

${ }^{48}$ Sobre esta cuestión, con algo más de detalle, MARTÍNEZ ALARCÓN, Ma L., "El derecho al secreto de las comunicaciones de los internos en establecimiento penitenciario con sus representantes legales", Revista Española de Derecho Constitucional, núm. 92, mayo-agosto 2011, pp. 147-150.

${ }^{49}$ En sus sentencias 145/1995, de 6 de marzo; 538/1997, de 23 de abril (RJ 1997\3259), y también, aunque como obiter, 513/2010. También habría que mencionar la propia sentencia del Supremo de 9 de febrero de 2012, FJ $8^{\circ}$.

${ }^{50}$ Es cierto que la sentencia del Tribunal Constitucional 73/1983, de 30 de junio, si bien en una declaración obiter dictum, realizó una interpretación extensiva del precepto en virtud de la cual se entendía que los presupuestos recogidos por el artículo 51.2 de la LOGP funcionaban alternativamente de tal forma que la intervención de estas comunicaciones podía autorizarse, bien por la autoridad penitenciaria en los supuestos de terrorismo (esto es, por el Director del establecimiento penitenciario), bien por la autoridad judicial en el resto de supuestos delictivos (que naturalmente debían consistir en tipos delictivos que revistieran cierta entidad). Algo más de una década más tarde, el Tribunal Constitucional rectificó su interpretación de la norma considerando que la doctrina sostenida en el año ochenta y tres no se ajustaba al sentido más estricto y garantista para el derecho fundamental (en concreto, y como puede comprobarse en el texto principal, en el año 1994). En todo caso, antes de esta rectificación del año noventa y cuatro, el Auto 
que el artículo 51.2 de la Ley Penitenciaria permite la suspensión e intervención de las comunicaciones del recluso con sus representantes legales en un único supuesto delictivo y solamente cuando, además, es ordenada judicialmente $^{51}$. Así pues, el régimen específico de esta intervención de las comunicaciones de los internos en establecimiento penitenciario y sus representantes legales desemboca, con la nueva interpretación constitucional, en una radical disminución de las posibilidades de someterla a limitación (solamente en el caso de delitos de terrorismo y, necesariamente, por mediación de una autorización judicial) $)^{52}$.

Es cierto, por otra parte, que algún sector doctrinal -si bien minoritario $^{53}$ - ha defendido la aplicación del artículo 579 del Código procesal Criminal. Además, los autores que se han pronunciado sobre la interpretación de estas dos condiciones recogidas en el artículo 51.2 de la Ley Penitenciaria no lo han hecho de forma unánime (existen opiniones contrapuestas tanto antes como después del viraje jurisprudencial del Constitucional del año noventa y cuatro). En efecto, no todos defienden la acumulación de estos dos requisitos sino que, antes bien, los presentan como alternativos por diversas razones (recurriendo a la interpretación conforme a la voluntad del legislador -especialmente, ARRIBAS LÓPEZ -54 , o poniendo de manifiesto la incoherencia que

de 20 de diciembre de 1993 (caso Gorostiza) de la Sala de lo Penal de la Audiencia Nacional, ya había contradicho las afirmaciones vertidas por el Tribunal Constitucional en la sentencia 73/1983 (considerando que no cabía autorización administrativa en los delitos de terrorismo). Un comentario de este Auto puede verse en MARCHENA GÓMEZ, M., "La inferencia de la Administración Penitenciaria en las comunicaciones del interno con su abogado. (A propósito del Auto de la Audiencia Nacional...)”, ob. cit., pp. 298299.

${ }^{51}$ Reitera esta doctrina en las sentencias 197/1994, de 4 de julio, o 58/1998, de 16 de marzo.

${ }^{52}$ LÓPEZ YAGÜES, V., La inviolabilidad de las comunicaciones con el Abogado..., ob. cit., pp. 261-262. Una valoración positiva de este cambio de jurisprudencia en MARTÍNEZ ALARCÓN, Mª L., "El derecho al secreto de las comunicaciones de los internos en establecimiento penitenciario con sus representantes...", ob. cit., pp. 152-154.

${ }^{53}$ CARRILlO, M., "El juez ante las escuchas telefónicas", El Pais, 25 de marzo de 2010. Nosotros, por el contrario, compartimos plenamente la opinión sostenida por PELAYO, para quien la Ley Orgánica de Régimen General Penitenciario no es una especie de "norma administrativa" (tal y como algunos pretenden). Es una Ley Orgánica porque regula derechos fundamentales de los internos. Y, además, por afectar precisamente a este sector de la población (internos en prisión, bien preventivamente, bien condenados), es la norma especial aplicable a este supuesto; PELAYO, R.C., "Intervención de las comunicaciones entre Abogado y cliente. Intromisión ilegítima en el derecho a la...", ob. cit.

${ }^{54}$ En nuestra opinión, esta regla de interpretación atendiendo a la voluntad del legislador conduce a resultados diferentes de aquélla que ha de resultar preferente y en virtud de la cual las normas que limitan derechos fundamentales deben interpretarse de forma restrictiva (especialmente en un caso como éste en el que nos encontramos con una regulación del año setenta y nueve -recordemos que la Ley Penitenciaria es la primera Ley Orgánica de desarrollo de la Constitución que se aprobó-. 
puede suponer mantener la interpretación acumulativa de los mismos ya que, mientras para los que permanecen fuera de la prisión podría, llegado el caso, producirse una intervención de sus comunicaciones con sus letrados en supuestos ajenos al de terrorismo, esto no sería nunca posible en el caso de los internos en establecimiento penitenciario - por ello se refieren a la existencia de una especie de régimen privilegiado que les beneficia claramente- $\left.-{ }^{55}\right)^{56}$.

${ }^{55}$ Es verdad, la interpretación restrictiva de la norma impide, radicalmente, la limitación de las comunicaciones de los internos en establecimiento penitenciario con sus representantes legales cuando se trata de causas ajenas al terrorismo. Sin embargo, ello no supondría la creación de una especie de limbo jurídico que permitiera a los representantes legados implicados en una causa penal no terrorista, en la que intervienen o pretenden intervenir en calidad de tales, aprovecharse de tal situación para obstruir la efectiva realización del ius puniendi estatal. El Abogado imputado en la causa debe ser separado de la misma, y, además, puede ser investigado por otros procedimientos distintos a aquel relativo a una intervención de las comunicaciones con sus clientes. Quizás, y siempre teniendo en cuenta la excepcionalidad que hay que predicar respecto de la intervención de este tipo de comunicaciones, podría el legislador acometer una reforma para permitirla con relación a otro tipo de delitos de especial gravedad (no sólo para delitos de terrorismo). En todo caso, con la necesaria autorización judicial. Pero es una labor ésta que compete al legislador porque, en el marco de la interpretación constitucional, el juez sólo puede hacer una interpretación restrictiva de la norma que limita derechos fundamentales. En parecidos términos, REVIRIEGO PICÓN, F. y BRAGE CAMAZANO, J., "Relación de sujeción especial e intervención de las comunicaciones entre los reclusos y sus...", ob. cit., p. 71.

${ }^{56}$ Entre otros, ARRIBAS LÓPEZ, E., en "Sobre la intervención de las comunicaciones entre los internos y sus abogados en el ámbito penitenciario", Aranzadi, núm. 288, 2009, y en "Algo más sobre la intervención de comunicaciones de los internos con sus abogados: la voluntad del legislador", La Ley, núm. 7435, 2010; ATIENZA, M., "El caso Gürtel y la objetividad del derecho", Revista on line del Colegio Notarial de Madrid, núm. 31, p. 3; JIMÉNEZ VILLAREJO, J., "Intervención de comunicaciones entre internos y sus letrados", El Cronista. Iustel, núm. 14, junio 2010, pp. 70-71. Defendiendo, por el contrario, la complementariedad de los presupuestos legitimadores de la limitación, LÓPEZ YAGÜÉS, V., La inviolabilidad de las comunicaciones con el Abogado..., ob. cit., p. 263 (quien sigue así, en este sentido, a autores tales como ALONSO BARRERA, ALONSO PÉREZ, MONTAÑÉS PARDO, RÍOS MARTÍN, RODRÍGUEZ ALONSO, TAMARIT SUMALLA, SAPENA GRAU Y GARCÍA ALBERO, PAZ RUBIO); REVIRIEGO PICÓN, F. y BRAGE CAMAZANO, J., "Relaciones de sujeción especial e intervención de las comunicaciones entre los reclusos y sus...", ob. cit., pp. 69-71; MARTÍNEZ ALARCÓN, Ma L., "El derecho al secreto de las comunicaciones de los internos en establecimiento penitenciario con sus representantes...", ob. cit., p. 152-154; LÓPEZ-BARAJAS PEREA, I., "La postulación y los derechos a la tutela y de defensa: la confidencialidad de las relaciones con el Abogado defensor y sus...", ob. cit., pp. 131-132; PELAYO, R.C., "Intervención de las comunicaciones entre Abogado y cliente. Intromisión ilegítima en el derecho a la defensa", Actualidad Jurídica Aranzadi, núm. 795, marzo de 2010; BRAGE CAMAZANO, J., “¿Caballo de Troya? De pinchazos telefónicos y abogados", El Heraldo del Henares, 12 de octubre de 2009; MONTERO HERNANZ, T., "La intervención de comunicaciones en el ámbito penitenciario. (A propósito de las escuchas del caso Gürtel”, La Ley, núm. 7335, 2010, p. 3; NISTAL MARTÍNEZ, J., "La libertad de las comunicaciones con el abogado defensor como garantía del derecho a la defensa", La Ley, núm. 7383, 2010, p. 12. 
Conforme a esta última corriente de pensamiento, por tanto, se podría llegar a justificar la actuación de D. Baltasar Garzón, esto es, la autorización de la intervención de las comunicaciones de los internos en establecimiento penitenciario con sus representantes legales más allá del supuesto de los delitos de terrorismo.

Pues bien, como consecuencia de la insuficiencia, ambigüedad y complejidad normativa de la regulación española sobre la intervención de las comunicaciones en general, y más específicamente, sobre la intervención de las comunicaciones de los internos en un establecimiento penitenciario con sus representantes legales, y ante tanta discrepancia, sobre todo con relación a la naturaleza acumulativa o alternativa de las dos condiciones recogidas en el artículo 51.2 de la Ley Orgánica General Penitenciaria, y dando por supuesto que la discrepancia se asienta realmente en presupuestos científico-jurídicos y no tanto en consideraciones de naturaleza política, ya afirmamos en su momento que difícilmente se podía concluir que, en este caso, se había producido una inobservancia manifiesta del Derecho aplicable. Aunque también advertimos de que la suposición de que el Magistrado Instructor había prevaricado no era, como algún autor afirmó en su momento ${ }^{57}$, totalmente ridícula, o bien que respondiera siempre y en todo caso a motivos inconfesables. Porque la lectura de los Autos por los que se autorizó y prorrogó la intervención de estas comunicaciones ponían de manifiesto la existencia de varios puntos flacos en su actuación. Esto es, haber utilizado una interpretación imposible del artículo 51.2 de la Ley Penitenciaria para justificar su actuación según jurisprudencia del Tribunal Constitucional y haber decidido la intervención igualmente de forma absolutamente incompatible con la jurisprudencia constitucional; de forma genérica afectando a todos los abogados de la causa, aparecieran o no imputados en la misma, y, por tanto, con una finalidad meramente prospectiva (y recordemos, de nuevo, que las resoluciones de nuestro Alto Tribunal constituyen fuente del Derecho $)^{58}$.

Por ello, no nos ha sorprendido la conclusión a la que finamente ha llegado el Tribunal Supremo admitiendo la prevaricación. Para este órgano, "ninguno de los métodos de interpretación del derecho usualmente admitidos que hubiera podido seguir el acusado respecto de esos preceptos, le habría conducido a concluir de forma razonada que es posible restringir sustancialmente el derecho de defensa, con los devastadores efectos que ocasiona en el núcleo de la estructura del proceso penal, en las condiciones en que lo hizo", esto es, sin disponer de indicio de responsabilidad criminal alguno contra la mayoría de los Abogados sobre la utilización de su condición de letrado y del ejercicio del derecho de defensa como coartada para delinquir (no olvidemos que únicamente se menciona individualizadamente en sus Autos al letrado D. José

${ }^{57}$ Así, ATIENZA, M., "El caso Gürtel y la objetividad del...”, ob. cit., p. 1.

${ }^{58}$ MARTÍNEZ ALARCÓN, Ma L., "El derecho al secreto de las comunicaciones de los internos en establecimiento penitenciario con sus representantes...", ob. cit., p. 164. 
Antonio López Rubal y que algunos de ellos -como los letrados defensores Choclán, Mourullo y Peláez y Vergara-, se incorporaron a la causa con posterioridad a su primer Auto de 19 de febrero de 2009 y jamás se hizo referencia a los mismos en las subsiguientes actuaciones del Magistrado de tal forma que sus conversaciones con los internos en establecimiento penitenciario también resultaron intervenidas ${ }^{59}$ ).

\subsection{El elemento subjetivo del ilícito (el dolo)}

Para que exista el tipo que describe el artículo 446 del Código penal no basta con que concurra el elemento objetivo, esto es, la acción de dictar resolución injusta (que, ya hemos visto, se produce por un grave apartamiento del Derecho o de los criterios de racionalidad en la valoración del resultado probatorio). Además, es preciso que concurra el elemento subjetivo, en virtud del cual, dicho apartamiento debe producirse de forma consciente y voluntaria ("a sabiendas"), o, lo que es lo mismo, con dolo ${ }^{60}$. Así pues, mientras que el elemento objetivo del ilícito consiste en que lo acordado no es defendible en Derecho, ni se podría llegar a ello por alguno de los métodos de interpretación admitidos en Derecho, la concurrencia del elemento subjetivo implica que se da el conocimiento de que concurre el tipo objetivo.

Para el Tribunal Supremo resulta claro que Garzón actuó "a sabiendas" de que no contaba con cobertura legal, aunque fuera con la finalidad metajurídica de garantizar la eficacia en la persecución del delito (el ahora ex Magistrado insistió durante el proceso en que adoptó la medida porque no había otra solución para impedir que los imputados continuaran con su actividad delictiva). Para el intérprete supremo de la legalidad ordinaria, "la investigación criminal no justifica por sí misma cualquier clase de actuación y con

${ }^{59}$ De hecho, la querella la presenta uno de los Abogados a los que después se adherirían las demás acusaciones particulares. Por otra parte, el fundamento jurídico noveno de la resolución que comentamos recuerda que el Proyecto del nuevo proceso penal que aprobó el Gobierno de la Nación en la anterior legislatura (y que decayó al finalizar ésta), permitía la intervención telefónica de las conversaciones entre la persona investigada con su abogado "solo cuando concurran indicios fundados que permitan afirmar su participación en el hecho delictivo investigado". En esos casos, además, el Ministerio Fiscal debería solicitar al juez la exclusión del letrado, lo cual daría lugar a una nueva designación (precisamente para evitar la lesión del derecho de defensa).

${ }^{60}$ STS de 14 de mayo de 1914: la expresión "a sabiendas" es sinónimo de "dolo" e implica un "ánimo deliberado del reo de faltar a la justicia". STS de 3 de mayo de 1983: el juez "sabe y le conste que la resolución que dicta es injusta por contrariar la ley y que, no obstante, la dicte voluntaria y conscientemente". En el mismo sentido, las sentencias del Tribunal Supremo de 9 de julio de 1999, FJ $8^{\circ}$ (RJ 1999\5881); 14 de julio de 1999, FJ $3^{\circ}$ (RJ 1999 7363 ). Por otra parte, el fundamento jurídico sexto de la sentencia del Tribunal Supremo de 9 de febrero de 2012 que venimos analizando reitera esta jurisprudencia, explicitando, en su fundamento jurídico décimo los hechos que prueban en este supuesto la concurrencia del elemento subjetivo del tipo. 
mayor razón si implica vulneración de derechos fundamentales (la verdad no puede alcanzarse a cualquier precio)".

Probablemente, erró la defensa de D. Baltasar Garzón al plantear su estrategia. Y es que, quizás, la sentencia del Supremo no hubiera sido la misma si el acusado se hubiera centrado durante el proceso en discutir la aplicabilidad del artículo 51.2 de la Ley penitenciaria, y, sobre todo, su posible interpretación (o, al menos, si no hubiera utilizado jamás el argumento relativo a la búsqueda de esa especie de fin metajurídico al que nos referíamos supra). Habida cuenta la doctrina contrapuesta existente sobre la aplicabilidad y la interpretación de dicho precepto, quizás el Supremo habría podido concluir que, en este supuesto, no se había producido una inobservancia manifiesta del Derecho aplicable, o, por lo menos, que el acusado no había actuado con dolo, sino con culpa grave. Pero, una vez que el acusado parece admitir, en ocasiones, que tiene pleno convencimiento de que está aplicando una norma que no ofrece cobertura legal alguna a su conducta, ¿qué más podía hacer el intérprete supremo de la legalidad sino condenar por prevaricación con dolo ${ }^{61}$ Añádase a esto, además, que tampoco la falta absoluta de indicios fue discutida durante el proceso penal ${ }^{62}$. Y que, dentro del tipo penal finalmente aplicado, la pena impuesta ha sido una de las más pequeñas posibles (recordemos que esta decisión del Supremo también ha sido criticada como consecuencia de la gravedad del castigo finalmente impuesto al acusado $)^{63}$.

\section{REFERENCIA BIBLIOGRÁFICA}

ANDRÉS IBÁÑEZ, P., "Las garantías del imputado en el proceso penal”, Revista Mexicana de Justicia, núm. 6, 2005.

${ }^{61}$ Téngase en cuenta, además, el cambio de criterio del Magistrado sobre la norma aplicable al caso. Llega un momento en que alega la aplicación del artículo 579 LECrim cuando sus Autos se asentaban en el artículo 51.2 de la Ley Orgánica General Penitenciaria (esto lleva a sospechar que el Magistrado fue consciente en algún momento de su error y por ello modificó su versión).

${ }^{62}$ Por otra parte, la sentencia del Tribunal Supremo de 9 de febrero de 2012 apunta que su Sala segunda nunca ha decidido sobre un caso similar. Se han anulado, sí, intervenciones telefónicas de conversaciones de letrados, pero en este supuesto, primero, se contaba con la cobertura legal -si bien parca o insuficiente- del artículo 579 LECrim, y, segundo, se discutía sobre la suficiencia de los indicios que se alegaban para justificar la intervención (en el presente caso, ni el artículo 579 LECrim da cobertura a la actuación de D. Baltasar Garzón que, además, se produce en el marco de la inexistencia absoluta de indicios).

${ }^{63}$ Se ha dicho, incluso, que "la sentencia está dictada con mala índole y extraña que algunos magistrados hayan caído en ese juego"; BASTIDA FREIJEDO, F., "Garzón, ¿la condena a una persona o al personaje?", contraposición.blogspot.com.es/p/francisco-bastida-freijedo.html. Y advierte de que lo único que querría el ciudadano es que este rigor con el que el Supremo ha condenado a Garzón se aplicase también siempre, comenzando por el propio Tribunal Supremo (reprocha la prevaricación de las sentencias del caso Parot o de las que resolvieron de forma distinta el caso Botín y el caso Atutxa). 
ARRIBAS LÓPEZ, E., "Sobre la intervención de las comunicaciones entre los internos y sus abogados en el ámbito penitenciario", Aranzadi, núm. 288, 2009.

- "Algo más sobre la intervención de comunicaciones de los internos con sus abogados: la voluntad del legislador”, La Ley, núm. 7436, 2010.

ATIENZA, M., "El caso Gürtel y la objetividad del Derecho", Revista on line del Colegio Notarial de Madrid, núm. 31.

BASTIDA FREIJEDO, F., "Garzón, ¿la condena a una persona o al personaje?", contraposición.blogspot.com.es/p/francisco-bastida-freijedo.html.

BRAGE CAMAZANO, J., “¿Caballo de Troya? De pinchazos telefónicos y abogados", El Heraldo del Henares, 12 de octubre de 2009.

CANO PALOMARES, G., "El diálogo entre tribunales y el derecho al secreto de las comunicaciones telefónicas (a propósito de la decisión Coban c. España del Tribunal Europeo de Derechos Humanos de 25 de septiembre de 2006)", Revista Española de Derecho Europeo, núm. 24, 2007.

CARRILLO, M., "El Juez ante las escuchas telefónicas", El País, 25 de marzo de 2010.

CATALÁ I BAS, A.H., "Escuchas telefónicas: un encuentro con el Tribunal Constitucional y un desencuentro con el legislador español", Revista Europea de Derechos Fundamentales, núm. 15, 2010.

CUELLO CONTRERAS, J., "Jurisprudencia y prevaricación”, RJELL, 11993.

ELVIRA PERALES, A., "El derecho al secreto de las comunicaciones a golpe de jurisprudencia", ESTUDIOS SOBRE LA CONSTITUCIÓN ESPAÑOLA: Homenaje al profesor Jordi Solé Tura, Cortes Generales, CEPC, Universitat de Barcelona y Ajuntament de Mollet del Vallés, Madrid, 2008.

FASSONE, E., "Il giudice tra independenza e responsabilità", Rivista Italiana di Diritto e Procedura Penale, I, 1980.

FERNÁNDEZ ESPINAR, G., "El levantamiento del secreto de las comunicaciones telefónicas en el marco de las diligencias de investigación y aseguramiento en el proceso penal”, Poder Judicial, núm. 32, diciembre 1993.

FERRAJOLI, L., Derecho y razón. Teoría del garantismo penal, ed. Trotta, Madrid, 2004.

GARCÍA ARÁN, M., La prevaricación judicial, ed. Tecnos, Madrid, 1990.

GARCÍA VALDÉS, C., Comentarios a la legislación penitenciaria, $2^{\mathrm{a}}$ ed., ed. Cívitas, Madrid, 1982.

GIACOBBE, G., "La responsabilità del giudice: A proposito di una recente proposta di legge", In Iure Praesentia, 1980.

LÓPEZ-BARAJAS PEREA, I., "La postulación y los derechos a la tutela y de defensa: la confidencialidad de las relaciones con el Abogado defensor y sus límites", Revista de Derecho Político, núm. 79, septiembre-diciembre 2010 . 
MARTÍNEZ ALARCON, Mª L., La independencia judicial, CEPC, Madrid, 2004.

—_La aplicación judicial del Derecho constitucional”, Teoría y Realidad Constitucional, núm. 21, 2008.

- "El derecho al secreto de las comunicaciones de los internos en establecimiento penitenciario con sus representantes legales", Revista Española de Derecho Constitucional, núm. 92, 2011.

MONTERO HERNANZ, T., "La intervención de las comunicaciones en el ámbito penitenciario. (A propósito de las escuchas del caso Gürtel)", $L a$ Ley, núm. 7335, 2010.

NISTAL MARTÍNEZ, J., "La libertad de las comunicaciones con el abogado defensor como garantía del derecho a la defensa", La Ley, núm. 7383, 2010.

JIMÉNEZ CAMPO, J., "La garantía constitucional del secreto de las comunicaciones", Revista Española de Derecho Constitucional, núm. 20, 1987.

—_La igualdad jurídica como límite frente al legislador", Revista Española de Derecho Constitucional, núm. 9, 1987.

JIMÉNEZ VILLAREJO, J., "Intervención de comunicaciones entre internos y sus letrados", El Cronista. Iustel, núm. 14, junio 2010.

LÓPEZ BARJA DE QUIROGA, J., Las escuchas telefónicas y la prueba ilegalmente obtenida, ed. Akal, Madrid, 1989.

LÓPEZ GARRIDO, D. y GARCIA ARÁN, M., El Código Penal de 1995 y la voluntad del legislador. Comentario al texto y debate parlamentario, Eurojuris, Madrid, 1996.

LÓPEZ-FRAGOSO ÁLVAREZ, T., Las intervenciones telefónicas en el proceso penal, ed. Colex, Madrid, 1991.

LÓPEZ YAGÜES, V., La inviolabilidad de las comunicaciones con el Abogado defensor, ed. Tirant lo Blanch, Valencia, 2003.

MARCHENA GÓMEZ, M., "La injerencia de la Administración Penitenciaria en las comunicaciones del interno con su abogado. (A propósito del Auto de la Audiencia Nacional de 20-12-1993)", Anuario de Derecho Penal y Ciencias Penales, t. 47, 1994.

MARTÍNEZ ALARCÓN, Ma L., "El derecho al secreto de las comunicaciones de los internos en establecimiento penitenciario con sus representantes legales", Revista Española de Derecho Constitucional, núm. 92, mayoagosto 2011.

MARTÍNEZ ESCAMILLA, M., La suspensión e intervención de las comunicaciones del preso, ed. Tecnos, Madrid, 2000.

MARTÍN MORALES, R., El régimen constitucional del secreto de las comunicaciones, ed. Cívitas, Madrid, 1995.

PELAYO, R.C., "Intervención de las comunicaciones entre Abogado y cliente. Intromisión ilegítima en el derecho de defensa", Actualidad Jurídica Aranzadi, núm. 795, marzo de 2010. 
QUINTERO OLIVARES, G. (dir.) y MORALES PRATS, F. (coord.), Comentarios a la Parte Especial del Derecho Penal, 20 ed., ed. Aranzadi, Pamplona, 1999.

REBOLLO DELGADO, L., "El secreto de las comunicaciones: problemas actuales", Revista de Derecho Político, núms. 48-49.

REVIRIEGO PICÓN, F. y BRAGE CAMAZANO, J., "Relaciones de sujeción especial e intervención de las comunicaciones entre los reclusos y sus letrados", Revista Europea de Derechos Fundamentales, núm. 16, segundo semestre 2010.

REVIRIEGO PICÓN, F., "El secreto de las comunicaciones en los centros penitenciarios: comunicaciones escritas "entre" reclusos", UNED. Boletín de la Facultad de Derecho, núm. 26, 2005.

RODRÍGUEZ RUIZ, B., El secreto de las comunicaciones: tecnología e intimidad, ed. MacGraw-Hill, Madrid, 1998.

SERRANO BUTRAGUEÑO, I. (coord.), Código Penal de 1995. (Comentarios y jurisprudencia), Granada, 1999.

VELASCO NÚÑEZ, E., "Presencias y ausencias (aspectos aclarados y discutidos) en materia de intervenciones telefónicas; en espera de una regulación parlamentaria del tema”, Revista de Actualidad Penal, núm. 18, 1993. 